\title{
Cultures Grow Exponentially An Interview with Rainer Görß
}

\section{Seth Howes}

This interview features Rainer Görß, a multimedia artist, curator, educator, who, since receiving his diploma from the Dresden Academy of Visual Art (HfBK), in 1989, has also been working, with Ania Rudolph, as co-director of the Underground Museum U144, in Berlin. He has exhibited mixed media art and performed actions in international galleries and museums from France, through Japan and Brazil, to the United States. The use of photography, film, and video has long been integrated into his work, whether in painting, sculpture, drawing, writing, or performance. His longstanding engagement with information technology has recently found expression in Görß's work through electronic media, especially data visualisations.

Keywords: Görß, East Germany, performance, installation, archive, temporality, growth, decay

Rainer Görß was born in Neustrelitz (the former GDR) in 1960, and raised largely in Berlin. He worked a variety of jobs, including as a chef and technician, and spent a stint as an intern at the Deutsches Theater before studying scenography at the Dresden Academy of Visual Art (HfBK), from which he received the first-ever multidisciplinary degree in 1989. This course of study, and in particular his diploma defence, an installation of artworks in a number of different media that also included performances by other students and lectures and performances by Görß himself, was so controversial that at the May 1989 HfBK faculty council's meeting, an agenda item was devoted to "the Academic and Artistic Profile of the Academy" with that item's 
first subsection reading, in the official minutes, "[Discussion of] the upcoming diploma of Rainer Gör $\beta$ (can only remain an exception)."

During his time at the Academy, Görß worked together with fellow Scenography students Else Gabriel, Via Lewandowsky, and Micha Brendel in a constellation called the Autoperforationsartisten [Eng. roughly: Autoperforationartists] whose pioneering combination of process-oriented art-making, performance, and other modalities ran counter to many of the exhibition procedures and educational approaches under which East German art operated. These inventive multimodal artists are best known today as practitioners of what was known in the GDR and elsewhere as Aktionskunst, or action-art, mounting installations and performances that often drew upon organic matter including cabbage, cow forelimbs, pig brains, blood, and flies. ${ }^{1}$ As Gör $\beta^{\prime}$ 's unprecedented dual-degree at the Academy attests, he and his fellow Autoperforationsartisten put pressure on the customary ways of teaching, making, and exhibiting art in

${ }^{1}$ Since 1989 this work has often been compared, especially by West German critics, to that of the Viennese Actionists. That the Actionists' mid-1960s work evolved in a quite different context (majority-Catholic Austria vs officially atheist, plurality-Protestant East Germany) from that in which the Autoperforationsartisten worked is stressed by the Autoperforationartists' frequent collaborator Durs Grünbein in a short essay entitled "Protestantische Rituale: Zur Arbeit der Autoperforationsartisten," in Andreas Koziol and Rainer Schedlinski, eds. Abriss der Ariadnefabrik (Berlin: Galrev, 1990), 297-306. The artists' complex and often critical relationship to contemporary art and artists in the West, especially West Germany, is discussed further by Constanze von Marlin in "Hyänen mit Kojoten vergleichen: Überlegungen zur Auto-Perforations-Artistik," in von Marlin, ed. Bemerke den Unterschied: Auto-Perforations-Artistik (Nürnberg: Verlag für modern Kunst, 2006), 35-44. On the Actionists' own ambit, see Cecilia Novero, "Painful Painting and Brutal Ecstasy: The Material Actions of Günter Brus and Otto Muehl," in Seminar: A Journal of Germanic Studies 43:4 (November 2007), 453-468. 
the GDR, breaking down disciplinary boundaries and confronting audiences with unaccustomed material.

One particularly well-known undertaking by the Autoperforationsartisten conveys a sense of their work's intellectual probity and physical rigor. The March 1988 action Allez! Arrest took place in the unofficial Leipzig gallery Eigen+Art as part of "nach beuys" [after Beuys], an event series in which GDR artists reflected on the legacy of the recently deceased West German artist Joseph Beuys (1921-1986), both in itself and with respect to the GDR art establishment's highly selective celebration of the West German artist's significance. There, three of the four Autoperforationsartisten-Brendel, Gabriel, and Gör $\beta$-were confined in the gallery space for 10 days, in purposeful evocation of Beuys's 1974 New York performance, I Like America and America Likes Me. ${ }^{2}$ Opening the gallery for a nightly encounter with gallery patrons, they traded the art that they had made in their confinementpaintings, drawings, poems, prints, and sculptures - for food and water.

In the gallery during those eight days, Görß produced (among other objects) works of the kind he now terms Biobilder, or bioimages. Introducing mould spores onto wet canvas treated with gelatine, and providing warmth, light, and further moisture as needed, Görß-clearly referencing organic work of the like of Dieter Roth's-allows the discolouration, wrinkling and weakening of the canvas caused by the fungus's growth to

2 On this connection, and for a detailed reconstruction of the relationship between Allez! Arrest! and the Autoperforationsartisten's other work, see Constanze Fritzsch's superb article "Allez! Arrest. Gelebte Wirklichkeit gegen tote Realität" OwnReality (25), 2016, online, URL :

https://perspectivia.net/receive/pnet mods 00000810 
produce non-figurative "images" on the canvas. ${ }^{3}$ Rather than remain static, the images instead change over time, at rates determined by the environmental factors driving the fungal life cycle. In the East German art context, where media such as easel painting and sculpture retained great prestige, and where the stylistic continuity of GDR art with earlier German and European artistic traditions was held to be of great importance, work like Görß's-performative, aleatory, abstract, and multimedial, and often exhibited under provisional and experimental conditions-made a striking departure from the customary ways of making and exhibiting "official" art.

Since receiving his diploma in 1989, Görß has worked as an artist, curator, and educator-both in Berlin, where he serves with Ania Rudolph as co-director of the Underground Museum U144 (http://www.untergrundmuseum.de), and in galleries and museums from France, through Japan and Brazil, to the United States. The use of photography, film, and video has long been integrated into his work in painting, sculpture, drawing, writing, and performance, as the photos of actions reproduced below attest. And while his recent work has also come to incorporate the products of electronic media, especially data visualisations, this can be seen less as a recent adoption as, rather, a new expression of an already-existing, indeed longstanding, engagement on Görß's part with information technology. Such an engagement stretches back to encounters with cybernetics and information theory that were integral to his above-mentioned 1989 diploma defence, entitled Midgard: Heaps of Heroes and Circuit Mythologies. For that defence, he had created a distinct "environment" for several actions: he filled the Dresden Academy of Arts with sculptures, paintings, bio-images, and installations

3 On Dieter Roth/Diter Rot see the Dieter Roth's Museum and Foundation (in Hamburg). URL: http://www.dieter-rothmuseum.de/en. Accessed on December 12, 2019. 
made from found objects, and scheduled there a series of performances, lectures, and public dialogues, which included participation by both current and former Academy students.

Another such environment is the contemporary Underground Museum that is located in the basement of Linienstraße 144 in Berlin. A Wunderkammer housing ephemera from several centuries of Berlin history, the Museum is divided into nearly a dozen rooms, through which Görß guides visitors as he lectures on their contents. One room, the "Foundry Shaft," reconstructs the history of industry in Berlin, presenting visitors with hundreds of stamped nameplates for buildings and vehicles, produced in a now-shuttered foundry in the vicinity of the Museum. He aims to show how serial production crowds out the Unikat, or the unique object. Another room helps him to advance the Prosthesis Thesis: here, he juxtaposes piles of artificial limbs and gas masks with anatomical models of human and posthuman figures, recalling all those attempts to repair bodies and transcend them. In addition to housing thousands of found objects, the Underground Museum also serves as a respository for Görß's own sculptures, paintings, performance utensils, and graphics: a blended archive of artifacts and artworks.

As I spoke to him in the early autumn of 2019, he and Rudolph were developing materials for inclusion in Grenzfälle 1989_2019: Hereinspaziert ins Labystan!, an exhibition that has just taken place in the Church of Zion in Berlin-Prenzlauer Berg (September 1- November 9, 2019). Taking this installation as its starting point, our conversation quickly turned to major turning points, or Wenden, in recent German political and cultural life-and from there to the enduring themes of his intellectual and artistic itinerary until now. While the term has become shorthand for the political and economic transition of 1989/90, whose aftershocks continue to roil German politics today, for Görß the Wende-which can mean "turn," "turning 
point," or even "reversal" - figures in a number of other contexts, from the climatic to the historiographical.

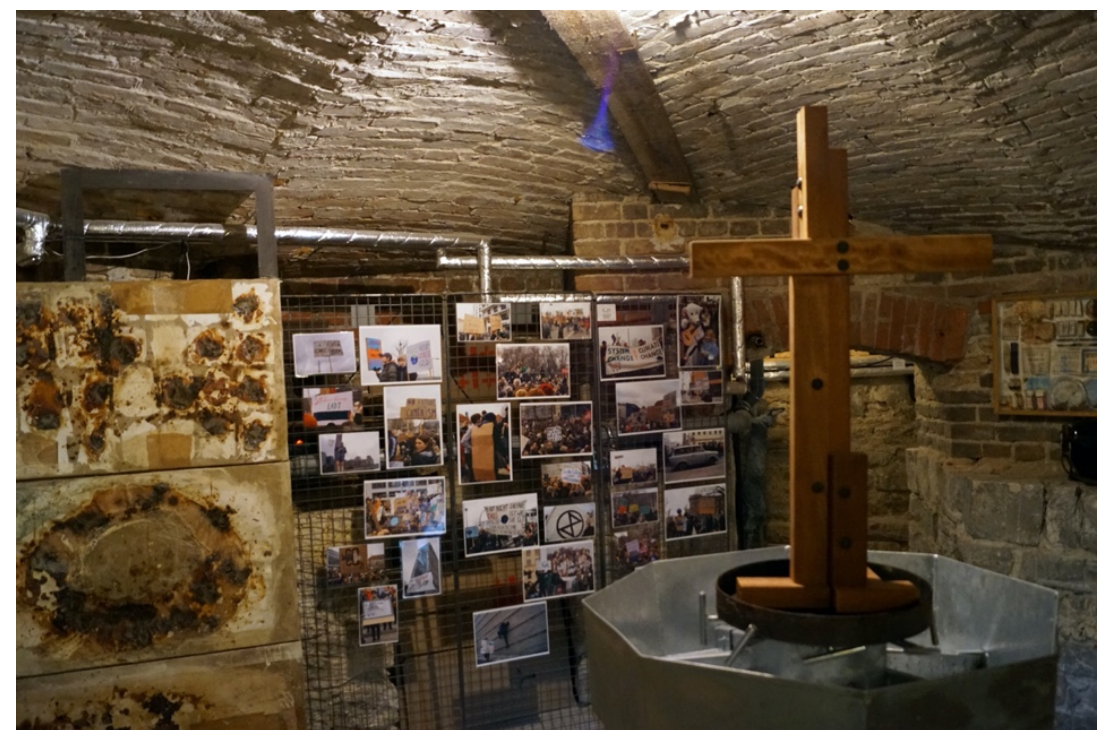

Rainer Görß, Cross (2019). Courtesy of the Artist. (C) Rainer Görß

Rainer Görß: At present, we're preparing the installation you can see in the picture I sent you, with the chapel.

Seth Howes: And that will be installed in the Church?

G: Exactly. I have to build the cross out of tropical wood. It's a cross in the centre of the installation, made of tropical wood, in the Bauhaus style. 
H: Where did you get the wood?

G: That's a strange story, with different levels of irony: first, the wood comes from the subflooring intended for the balconies of new apartments, condominiums. These buildings used to be the Party School of the Socialist Unity Party. ${ }^{4}$ An additional irony is that the subflooring beams themselves come from the rainforest but, in my installation, they change into a constructivist cross; in turn, the cross is going to end up in the location where the Umwelt-Bibliothek used to stand during the GDR. The latter, furthermore, was raided by the Stasi. ${ }^{5}$

${ }^{4}$ The Party University of the SED, to which he is referring here, was modeled on the Party University of the Communist Party of the Soviet Union in Moscow, and located in the Haus am Köllnischen Park in Berlin-Mitte. This so-called Kaderschmiede [Eng. "cadre smithy"] was an institution of postsecondary learning devoted to ideological education. On its current disposition, and projected future as a building full of condominiums, see Reinhart Bünger, DDR-Kaderschmiede wird Luxusklause," Tagesspiegel (31 October 2016).

${ }^{5}$ The Umwelt-Bibliothek [Environment Library] in the Church of Zion, located in the East Berlin district of Prenzlauer Berg, was founded in 1986 amid similar initiatives in other East German cities including Erfurt and Jena. Given the prominence of the Church of Zion as a venue for Berlin subcultures and oppositional groups more generally, and Berlin's significance within East Germany as a whole, it quickly became what Erhard Neubert calls "one of the communication centres of Berlin, and later the GDR[,] opposition." See Neubert, Geschichte der Opposition in der DDR, 1949-1989, $2^{\text {nd }} \mathrm{Ed}$. (Bonn: Bundeszentrale für politische Bildung, 2000), 629-632; here 630. The library became a target of disciplinary measures both from public-facing agencies such as the Ministry for Culture, which was responsible for licensing publishing activities, and from clandestine organs such as the Ministry for State Security. Görß refers here to the raid that occurred in November 1987. For his part, Neubert notes that "this action was . . . intended to criminalise the [library], but instead led to a mobilisation of the entire opposition and its affiliates in the GDR, catalysing an unbroken chain 
H: I'm sensing certain parallels here: restoration, reuse, the revaluation of all values. It all flows into, and from, the gentrification of Mitte, doesn't it?

G: In principle, yes, naturally. That's our current topic. We're currently preparing a project called Wertwenden, and that's the thing: the idea of a turn in values is quite current. Consider the discussion, for example, on the urgency of changing life-styles that has followed the demand for action initiated by FridaysForFuture. One asks for a turn with regard to the means of transport, the ways we practice agriculture, or we procure energy, not to speak of ecological justice. ${ }^{6}$

$\mathrm{H}$ : What form are these initiatives for change going to take?

G: This is a question of governmental policy. Take climate change, precisely: before the last UN Climate Action Summit (September 2019), before Greta Thunberg, individual nation-states had gathered to say we're going to do this, do that, etc. Then FridaysforFuture appears and everything comes together. Since this year marks 30 years since the Wende, you can also think of unification as a missed opportunity, since when else in recent times was an industrial state subjected to inventory, review, and liquidation? In 1989, there were projects [Thesen] for

of oppositional activities extending into the autumn of 1989, which the SED was no longer capable of mastering" (694).

6 Here Görß uses the suffix -wende to describe each political development I have labeled a "turn," lexically connecting them to the so-called Wende: the change, reversal, or turning point, of 1989. In what follows, I will leave Wende untranslated. 
something other than complete de-industrialisation; some had envisioned an industrial sector mindful of ecology, and proposed ways to transition; yet, this was completely missed at the time. Now, thirty years later, one needs to work on it. And what can we do? We can only tell stories about materials, and connect time-spaces to one another. ${ }^{7}$

H: On this point about time-spaces, I'd like to ask about your work Sehschlitz der Zeit [Eng. Aperture in Time, or A Crack to See Time]. It's a photograph of a room, partially obscured from our view by a wall or door, that seems to be filled with paintings, leaning against one another as if in storage. Could you please explain what it was, how it came about, what was there, and where it came from?

\footnotetext{
7 The German word Zeitraum (lit. time-space) customarily refers to a period of time or an era. Because an intellectual pivot-point of Rainer Görß's work involves bringing objects and artifacts from different times into spatial relationships with one another, or creating experiential spaces (such as his Underground Museum) in which different understandings of time-historical, anthropological, geologicalinteract with one another, I have chosen to render Zeitraum as "timespace," an admittedly awkward calque that has been used before, however (Walter Benjamin). While Mikhail Bakhtin's concept of chronotope could perhaps be productively applied to an analysis of Görß's work, Görß himself does not explicitly or implicitly invoke Bakhtin in his works, and so I use "time-space" instead.
} 


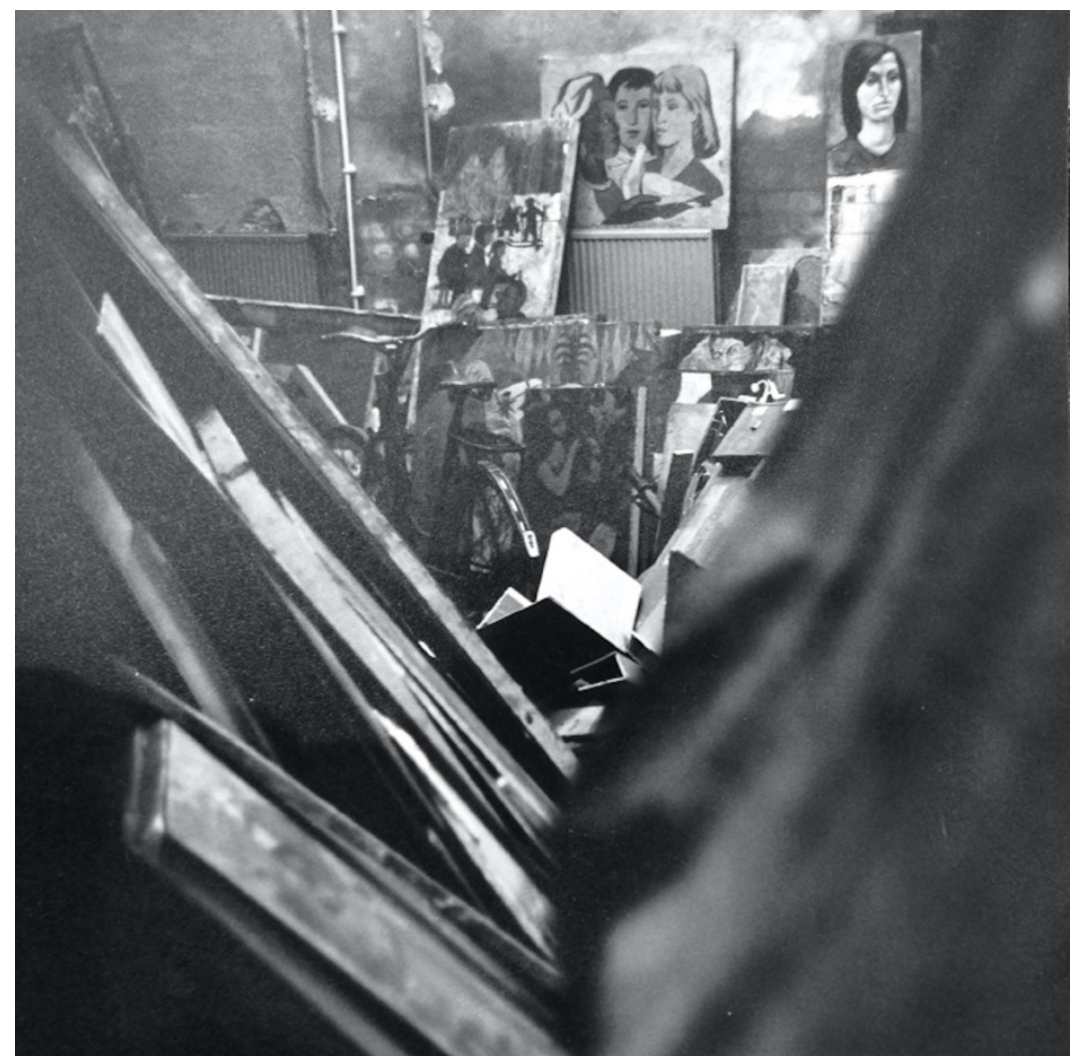

Rainer Görß, Der Sehschlitz der Zeit (1988). Courtesy of the Artist $($ C Rainer Görß

G: This fits well with what we were just talking about. In 1989, I was earning one of the first inter-disciplinary diplomas. In the GDR, art was divided up very conventionally: painting is painting, sculpture is sculpture, there's no such thing as performance, and so on. But in this time before the Wende, in 1988, some things were possible. We were able, for instance, to work as a performance group, 
and I studied stage design and painting and graphics in combination. What's completely normal today was sensational back then. Anyway, there was space at the classical Art Academy in Dresden, which they were willing to give me as a studio. It was under the old Dresden, beneath Brühl's Terrace. ${ }^{8}$ Place and history and material are all interconnected. In short, beneath the wartime rubble of this bourgeois-era Art Association, an underground space whose foundations were in the shape of an octagon or pentagon, had been spared from destruction. This was where Bondzin's classes in Socialist Wall-Decoration and Frescoe Painting had been held. He taught techniques and themes typical of socialist realism. You know the kind of art I mean: a picture of a red banner, or something like "Das Haus des Lehrers" (The Teacher's House) in Alexanderplatz, in Berlin, things like that. ${ }^{9}$

At the end of the 1980s, this [aesthetic] direction was being abandoned. It was understood, even before the Wende, that, well, such a programmatic disposition simply

8 Named after its builder Heinrich von Brühl, this pedestrian thoroughfare above the Elbe river has for nearly three hundred years provided views from Dresden's Friedrichstadt of its Neustadt. The main building of the Dresden Academy of Visual Art is located directly on the terrace.

${ }^{9}$ Gerhard Bondzin was a longtime professor at the Academy of Arts of the GDR. In the early 1970s, he had served as President of the country's Union of Visual Artists. "Das Haus des Lehrers," which Görß refers to here, is a large building on East Berlin's Alexanderplatz housing event spaces, meeting rooms, and offices for teachers' organizations. Rebuilt in 1964, the building bore (and bears) a large colorful mural, conceived by design professor and prominent GDR artist Walter Womacka. Görß refers to this mural as an example of socialist realism's mid-1960s apotheosis. On Womacka's reception by GDR art critics and cultural politicians, see Lothar Lang, Malerei und Graphic in Ostdeutschland (Leipzig: Faber \& Faber, 2002), 56-58. 
wasn't going to work any longer. So, they came to me, the weird guy, and proposed to throw me down there, in the dungeon, the underground room. The joke was that this was where that [Bondzin] class had taken place, and the space functioned like an archive. You see it in the background of my work: socialist realism at its apogee, diploma-pieces conceived and painted by many generations. Now the cork had been removed from an old bottle of wine, long forgotten in the cellar, and it was my idea to pour a glass: to bring this archive to the light. There was a partition wall dividing the space, with a gap in it. I took photographs through the gap. And I had constructed a tent there, you see it on the right-hand side of the photo, dark and diagonal as you look through into this space. In the tent were my bio-pictures. You can guess what was behind this idea: cultures establish themselves, expand, die off, thus bio-images. ${ }^{10}$ Naturally, they took a form that people only partially understood at the time. That's still the case in the current installation.

But to come back to the question we just raised, namely, the question of the environment: how do things come together, under what concept of culture, concept of value? That was the question [in 1988], too. Back then I already had this theory, these questions about the ideology of growth, all these questions: how long can we sustain the Workers' and Peasants' State, the Dictatorship of the Proletariat always accompanied by its Russian heavy industry and this ideology of growth? In the end, that socialist project didn't work out.

${ }^{10}$ These are the self-transforming, mold-based images described in the introduction. 
H: I've seen another caption for this photograph of the Sehschlitz: "Die Halbwertszeit der Bilder" [Eng. Half-Life of Images]. ${ }^{11}$

G: Yes, the Aperture in Time, the Half-Life of Images. That's the change in the concept of value. So, the murals were mostly agitative, or celebrated life and its circumstances. And in the sense of an atomic half-life, this concept from physics is applied to value-concepts for art, or for social agit-prop. It's all connected. You look at time, at a time-space that's past, and incorporate it into a greenhouse through these new questions, [posed by] the bio-pictures. At another level of abstraction, of course. ${ }^{12}$

H: Here I see the intersection of two conceptions of art. The prevailing assumption was that socialist realist images would have a very long half-life, that these murals of a bright future would serve as testament, across decades or even centuries, to the founders' values and vision. And would endure as stable snapshots preserving perspectives from the past for future generations. And that was everywhere in the GDR, no?

${ }^{11}$ In nuclear physics, the term "half-life" refers to the amount of time necessary for half the initially-present amount of a given radioactive isotope to decay. In German, the word "value" (Wert) is contained in the scientific term Halbwertszeit.

12 The way I-the interviewer-see it is this: 1950s/60s socialist realism has succumbed to natural decay according to the law of its own inherent half-life. What is left is decomposed organic material, a mass of imagery piled atop itself and now divorced from the social order in which it meaningfully circulated. This material can be brought into a new controlled context (that of the greenhouse) and serve as soil on which new artforms feed, and thrive. 
G: Yes, that was common, since there were catalogue titles like The Victors of History with such images in them, and we've got that in the archive, too. And not on paper, but on walls, on ceramic and stone: forever.

H: But then there are your images, which also have a halflife, guided by a completely different conception of the endurance of images, their dynamic rather than static properties. Your pictures, in particular the mould pictures, are not supposed to stay static and stable, remaining the same and bearing witness over decades, but rather they were supposed to move and change themselves, weren't they?

G: Yes. You know the Laboratory Bar [in the Underground Museum]? It gets a little damp in the summer, and then the mould spores come back to life. Because the genetic material is there. It comes from the environment, after all, and the genetic material is still there, or is added on. You prepare a growth medium on canvas, in the customary way, with the classic bone paste, really from animals, and then the spores in the air settle and start to expand, just like on a piece of bread. And then at some point it's all over, the energies have been consumed just like we're doing today with water, vegetation, and then nothing's left but the genetic material. But if new energy appears at some point, even humidity is enough, then there's the potential for it to all start again. And that happens again and again. With the majority of my projects, like the U-Boot [Underground Museum] I understand them as, in principle, a recycling process. Things that have been thrown away are read once more, in a new context, are interpreted, see these interpretations change. 
H: For example, in 1982 or ' 83 , you had climbed the tyre heap, so to speak, when you staged your Umlauf [Eng. circulation] action. Can you describe this action, where it took place, and how it was structured?

G: It was relatively straightforward. It was on the highway ring around Berlin: a heap [of tyres], just tossed into the brush. And the idea was to say: Umlauf, development is not linear, but rather cyclical. And with the help of a roll of receipt paper [for a cash register], I drew white lines: once vertically, once horizontally. The focus was on defining interconnection [Vernetzung] and value. Then there was also a scene with a crucifixion, a little theatrical but of course ironic, as well, intended to say: Hey guys, there's more over the horizon, but eventually we'll end up back where we started walking. The Earth is round. Forever forward's not the only direction things go; we'll just have to see. Thus in 1989, ostensibly taking a step forward, we ended up back in capitalism. Wonderful. And then the social market economy unmasks itself as neoliberalism, which wasn't part of anybody's analysis in 1989. 


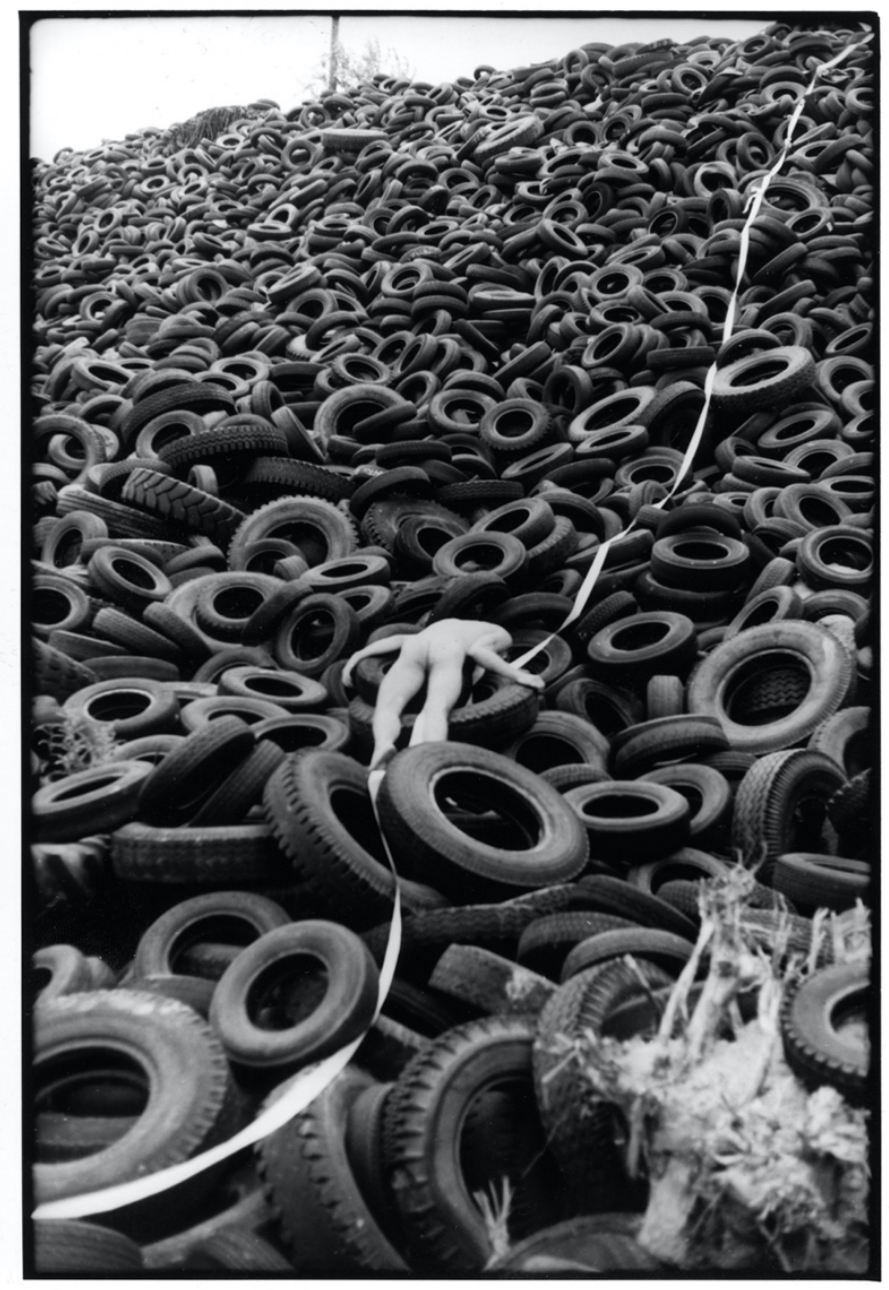

Rainer Görß, Umlauf (1982). Courtesy of the Artist (C) Rainer Görß 
H: And at that point, you entered a new form of circulation.

G: Yes, absolutely. After all Marxist theory recognises that everything moves in spiral forms, slowly ratcheting itself up in near-circles-that's Marxism's answer here. To be sure, not everything advances from lower to higher levels, for example a screw-shaped movement [i.e. a steeper spiral - S.H.] has an impact at least on climate, with temperature.

H: Yes, we see historical feedback loops. Again, take the Umlauf action: from today's perspective I think about the so-called "sacrifice zones" exposed over the long term to environmental damage. That tyre heap was such a zone, where they just dumped rubber waste. Some sacrifice zones appear suddenly, as with Chernobyl. Others aren't bound to specific areas, like-

G: Like the particular debris from tyres. A major source of plastic debris in the oceans, I understand, is debris from tyres. ${ }^{13}$ We didn't know this back then, of course, but just as a symbol it was so clear, so stinking black and heavy. Yeah, it was clear.

H: Can you think of tyre deposits and other sacrifice zones as long-term projects that grow over time and are managed, in capitalism and socialism alike, like items in a balance sheet?

\footnotetext{
${ }^{13}$ See Tik Root, "Tires: The Plastic Polluter You Never Thought About," National Geographic (September 20, 2019). Available online at https:/ / www.nationalgeographic.com/environment/2019/09/tiresunseen-plastic-polluter/ Accessed on November 26, 2019.
} 


\section{G: Yes, as if they're ruins.}

H: But you have to account for everything. It's entered into actuarial tables and subject to calculations and projections, "this is how much space we need for this output, this waste, our industry." But you entered the sacrifice zone.

G: Yes, that was absolutely at issue. That was a long-term issue. There is a series of works I produced called Depot Sinus, including a digging action in the city park of Bochum, after the Wende, aimed simply at clarifying once again that in the same place where I make a hole, there appears a heap. Taken together they make a sinus[oid shape]. That was a time-based action. In the Ruhr industrial area, too, I was interested in state reserves and energy. The point was to say, there's a cycle, positive, negative. There is a belief we were trying to call attention to, the belief that you can just create something, without something going missing somewhere else. But where there's a heap, there's also a hole in the world. Banal, sure, sounds like a children's story now. But it's true. We don't keep in mind that A doesn't disappear, and B doesn't come from nothing; because of the degree of abstraction we operate at, this never becomes clear to us. Native Americans have rituals for this, acknowledging debt to nature as a result of taking something from it. And this consciousness is returning again, just in the last ten years, as far as I can tell. In the industrialised societies it is slowly becoming more visible, an esoteric trend is emerging. We're completely frenzied at the moment. You guys aren't, yet. But we sent you Greta. 
H: Yes, by ship. Staying with Umlauf, on the topic of the human world and the environment. In your work from 1988/89 I see tendencies toward the anthropological, particularly with Midgard: Heaps of Heroes and Circuit Mythologies, your diploma installation at the Dresden academy. There you engaged with the ritual content of artforms, for example heathen fetishes of Germanic tribes that were not merely art-objects but possessed binding political and social force. So instead of socialist realism vs capitalist abstraction, or some other binary, there's a different framing.

G: Yes, the idea was to say, albeit in the necessarily encoded form one had to use in those days, "guys, there are always three components at play." Think about bipolarity in a different way. In this case, with the world of antiquity, the Christian God's world [and technical-industrial modernity], you've got a triangular dramaturgy. So: say something occurs, it's not because two things are opposed to one another, but because three things are interacting. It was a symbolic reference to the fact that all questions [refer to] the three components, the three dramaturgies, go way back [in time]. That was the idea behind it. You caught me.

$\mathrm{H}$ : I find interesting how prehistory or antiquity, the medieval world, and modernity interact and often interpenetrate one another in particular in the Underground Museum. For instance, in the room called "The Miracle of Interest". A space with an oil-on-canvas portrait of Father Stalin, printed currency, ingots, Libyan amber alongside GDR coins, and diagrams of finance. All in dialogue with one another. How do these time-spaces take shape? 
G: Once I remove linear or chronological thinking, and think thematically instead, then it doesn't matter what timeframe I'm operating in. It's a theme. In that case, the theme is conceptualizing value [Wertvorstellung], or maybe thinking of value as a culture of agreement [Verabredungskultur]. Of course, gold is worthless, from the Earth's perspective the difference between gold and mud is trivial. But we reach a consensus. On the basis of [gold's] characteristic of being beautiful. It's of course interesting that beauty, which is to say aesthetics, is involved here. But then it's also a question of growth, of expanded reproduction. In the case of the technology of iron-casting, we're talking simply about the way from the Unikat [unique object], the Bronze Age and so forth, to the series. It leads from the Bronze Age to the Fordist automotive assembly line. And all of this is a process we are still concerned with. I say, OK, all of these things are in the world, and if I bring them together into a single real space, and the [distinct] periods don't play a role, because the problems are right there, the main questions are still with us, whether in antiquity or in the present moment or in socialism as it collapses. That's the question: to say, "which aspects resonate with one another, while connecting to specific themes?" They all do. Everything's all there, after all. Everything that ever was, to put it cosmologically. And the question is: can we concentrate on an aspect that concerns the entire world?

H: But that requires a standpoint, no? Practically speaking-

G: Hard to say. You are always an axis, and things and stories turn around you. But "standpoint" is the wrong word, because how long can you stand at the same point? 
Everything, in its valuation, revolves around us. But you yourself don't stand too long in one place, unless you're forced to, like the soldier in front of Buckingham Palace. But even that has its limits. And we need to be cognisant of that movement, even if we accept the continuity of the posing of questions.

H: That's why I find the Sehschlitz in die Zeit so interesting. You took that picture in a certain moment. But it's a self-iterating problematic. You could imagine a Sehschlitz affording a perspective, from 40 years in the future, say, on Documenta or the Venice Biennale of today. And looking back at our present as the past, we could ask: what were the styles? What were the visions of the future?

G: You could take that in interesting directions. The Sehschlitz der Zeit is not completed yet, if you allow that the dominance of socialist murals, or even the fascist ones, or those from antiquity or even earlier, has been taken over by the graffiti scene, this youth- and street-based scene. Which is of course already in its Mannerist phase, taking commissions and so on. Or you could take a look at what was being articulated in these socialist idealisations in the 1950s and 1960s, considering what kinds of participatory, communal practices are being conceived today. I mean, we don't live in a system of total self-realisation; that's certainly not the case. And it comes back, just like in the mould pictures, the questions stay with us. Just like in the room about "The Miracle of Interest." The questions remain, life's questions. We can't just make art [ourselves]. It's always, by means of [passing] time, able to be interpreted or catalysed anew. 
H: Correct me if I'm wrong, but I also link the mould pictures to your food art actions.

\section{G: Absolutely.}

H: The larger context of man's metabolism with nature.

G: Right, that's the basis. Another historical point of reference. In Medieval churches there was a miracle bacterium, which brought forth the so-called Bleeding Host. It was the same reaction: damp church rooms, a growth medium. But, of course, these became the catalysts for anti-Jewish pogroms. ${ }^{14}$ It was through that that I first learned about the bacteria, and I thought, my God, the colour comes from the natural world, we see it in every flower in the meadow, but in this [ritual] context [it shocks and disturbs]. That was the main reason to engage with this, and then came the idea: what happens next, why does it occur, will it multiply, or stagnate, or disappear? I took it so far that I was working illegally with scientists at the Charité [Research Hospital in East Berlin], then with images from an electron microscope, and things like that. Today it stands for a principal subject [of my work], where I ask about the ideology of growth, about sustainability. Saying "Hi, hello there, let's maybe take it easy and think: what do we really need in order to live?"

$\mathbf{H}$ : On the subject of growth, and the ideology of growth, I find interesting that the art trade is one niche in a larger

\footnotetext{
${ }^{14} \mathrm{On}$ the phenomenon of the desecration of the host, and antisemitism in Germany, see Caroline Walker Bynum, "THE PRESENCE OF OBJECTS: Medieval Anti-Judaism in Modern Germany," Common Knowledge 10:1 (2004), 1-32.
} 
process of speculation. It circulates, and art can be "deposited".

G: In these customs-free warehouses at airports. ${ }^{15}$

H: Precisely. Where you remove art from conventional circulation so that it accumulates interest.

G: And this, of course, in a policy era of low interest rates. Completely logical, all of it. But it also demonstrates once again that aesthetic value is only a question of agreement, because you could collect works by a completely different artist or acquire some other piece. It's not about the art, it's about agreement. Without the communicative process, you can just leave the painting in its crate at airport $X Y Z$, and that's that. It's all just communication about concepts of functionality or concepts of value. It's not really important what's accumulated in the safe.

H: A final question: I'd like to hear something about the fingernail action. Thirty years ago, you crossed the border between East and West Germany with mould spores under your fingernails.

G: Now we're back to the bio-pictures. It was about transporting [translating] culture. The story went: let's bring culture to the West. Some background. We had an

${ }^{15}$ Annegret Erhard, "Die geheimen Museen im Niemandsland," Welt (August 31, 2014). Available online at $<$ https: / / www.welt.de/ kultur/ kunst-undarchitektur/article131751866/Die-geheimen-Museen-imNiemandsland.html $>$ Accessed on November 26, 2019. 
exhibition before the Wall opened, maybe two weeks before, and I think ... I still haven't read the files, but I think that it was the Stasi's plan for our group, the Autoperforationsartisten, "we can get rid of these four people." It worked with three of the four. And my action was to say, OK, I'm going to draw on Midgard, so German mythology, and take this genetic information with me, under my fingernails, across the border. It'll be an act of colonisation and I'm going to create a growth medium, using West German gelatine of course, top notch, and implant [the bacteria] there. And, of course, it worked. In the Church this Fall, by the way, the pictures are going to be there.

\section{H: The mould pictures?}

G: Yes, they're there. With a legend attached. Clearly, they had to return to the church, because with the Bleeding Host story they originated in the church . . . So anyway, that's what [the fingernail action] was. But then the Wall opened for real, and nobody cared anymore about the symbolic or esoteric stuff anymore. That's my impression. The action was in the street, the social commotion was there. But I'm glad I did it, from today's perspective. Makes for a good story. 


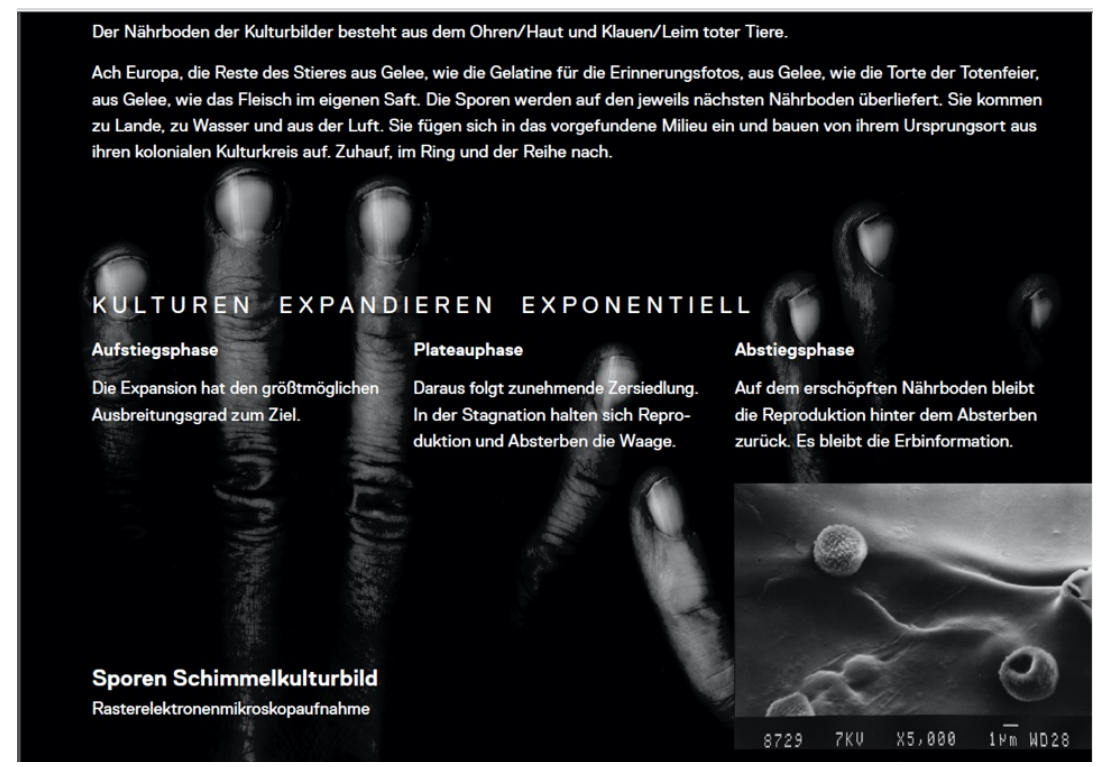

Rainer Görß, Kulturen wachsen exponentiell (1989/2019). Courtesy of the Artist (C) Rainer Görß

$\mathrm{H}$ : The bacteria are still growing, of course. The genetic material is there.

G: Yes, absolutely. They'll still be doing that when you and I aren't around to talk. They come from a long way away, and will still be there when there aren't any more ecological discussions, just ecology. A more or less functional ecology. And we won't bring the bacteria under our power, into our sphere of influence. We can't spoil them, or destroy them. 